\title{
Special Edition Interview with Dr. Marilynn Wood I Édition spéciale - Entrevue avec Dre Marilynn Wood
}

\author{
Sioban Nelson \\ University of Toronto, sioban.nelson@utoronto.ca \\ Pauline Paul \\ University of Alberta, ppaul@ualberta.ca
}

Follow this and additional works at: https://qane-afi.casn.ca/journal

Part of the Nursing Commons, and the Scholarship of Teaching and Learning Commons

\section{Recommended Citation}

Nelson, Sioban and Paul, Pauline (2020) "Special Edition Interview with Dr. Marilynn Wood | Édition spéciale - Entrevue avec Dre Marilynn Wood," Quality Advancement in Nursing Education - Avancées en formation infirmière: Vol. 6: Iss. 2, Article 12.

DOI: https://doi.org/10.17483/2368-6669.1270

This Interview is brought to you for free and open access by Quality Advancement in Nursing Education - Avancées en formation infirmière. It has been accepted for inclusion in Quality Advancement in Nursing Education - Avancées en formation infirmière by an authorized editor of Quality Advancement in Nursing Education - Avancées en formation infirmière. 


\section{Special Edition Interview with Dr. Marilynn Wood}

\section{Interviewee: Dr. Marilynn Wood}

Interviewers: Dr. Sioban Nelson \& Dr. Pauline Paul

Dr. Nelson: Welcome and thank you very much Marnie for finding the time to speak to us today. This interview is for the special issue we are doing on the history of nursing education. Pauline and I [the co-editors of the special issue] thought it would be wonderful to discuss some of the really important developments in nursing education in Canada that quite a lot of our faculty and the members of the profession more generally might not have a sense of. In particular, the collaborative programs and the importance of collaborative programs in Canadian nursing education. We of course thought of you as one of the key people in the development of collaborative programs and in encouraging the collaborative programs to push forward the entry-to-practice at a baccalaureate level, and because the University of Alberta was a key player in this story, we would be really interested in your reflections on how this was accomplished, in bringing the hospital schools and the colleges all together around baccalaureate education.

Dr. Wood: It started through our meeting together. I came to Alberta in 1987, and that was the same year that Heather Andrews was appointed as the director of the university hospital school of nursing and Irene Gataint was the head of nursing at Red Deer College then. The three of us stayed in our positions long enough to ensure that the collaborative effort happened, which was the largest ever seen in nursing education in Canada. So it takes us back a long way back to 1991, which is the year when the larger collaborative program was approved and started. Initial planning had begun a few years earlier, around 1985, when the people from Red Deer College, Irene Gataint and Shirley Chance, and Dr Janet Ross Kerr from the university

\section{Édition spéciale - Entrevue avec $D^{\text {re }}$ Marilynn Wood}

\author{
Invitée : $D^{r e}$ Marilynn Wood
}

\section{Intervieweuses : $D^{\text {re }}$ Sioban Nelson et $D^{\text {re }}$ Pauline Paul}

$D^{\text {re }}$ Nelson : Bienvenue, Marnie, et merci beaucoup de prendre le temps de discuter avec nous aujourd'hui. Cette entrevue fera partie d'une édition spéciale portant sur l'histoire de la formation en sciences infirmières. Pauline et moi (coéditrices de l'édition spéciale) avons pensé qu'il serait fantastique d'aborder quelques-unes des très importantes avancées dans ce domaine au Canada, qui pourraient avoir échappé à l'attention d'un bon nombre de notre personnel enseignant et des membres de la profession en général. Je pense en particulier aux programmes de collaboration et de leur importance dans la formation en sciences infirmières au Canada. Nous avons alors pensé à vous, l'une des joueuses clés dans la création de ces programmes et dans leur défense, afin de faire du baccalauréat en sciences infirmières la norme pour accéder à la pratique. Et puisque la University of Alberta a joué un rôle essentiel dans l'histoire, nous aimerions vraiment avoir votre point de vue sur le parcours de cette réalisation, qui réunit les collèges et les écoles en milieu hospitalier autour de la formation au baccalauréat.

$D^{\text {re }}$ Wood : Tout cela a commencé par une rencontre. Je suis arrivée en Alberta en 1987, l'année où Heather Andrews a été nommée directrice de l'école des sciences infirmières en milieu hospitalier et où Irene Gataint dirigeait le programme en sciences infirmières au Red Deer College. Nous avons toutes trois occupé nos postes assez longtemps pour aboutir à un effort de collaboration, le plus grand jamais vu en matière de formation en sciences infirmières au Canada. Ce qui nous amène à 1991, soit il y a bien longtemps, année de l'autorisation et du lancement du plus important programme de collaboration. La planification initiale avait été entamée 
developed a model for nursing education in which a four-year baccalaureate program could be delivered on campus at Red Deer College by the University of Alberta Faculty of Nursing, where the students would receive a degree from the university. That was the beginning of collaborative education; however, the program didn't start until later. When I arrived in 1987, we had to submit another proposal to get it going. The government was slow to move and give out money; they didn't move ahead on their own. They required prodding.

Even farther back, in 1975, the Alberta government had had a task force in nursing education and issued the first statement on baccalaureate entry-to-practice in Canada. Their position was endorsed by the Alberta Association of Registered Nurses a year later, and then came the idea to support baccalaureate entry-to-practice by 1995 . This became a call word for all involved; this is what we were aiming for. Even though the government tried to shelve the plan at their own committee's recommendation, the profession didn't let that happen. However, it took 15 years before the voice of nursing became increasingly united in Canada as one provincial nursing association after another committed to the position that all new nurses should be qualified at the baccalaureate level. In 1980, they debated the resolution on the minimum educational qualifications needed to enter nursing, and the committee was appointed to study the issue. There were articles in Canadian Nurse dealing with both sides of the question. The Canadian Nurses Association (CNA) board decided to endorse the baccalaureate standards in 1982. It was highly supported at that time within the profession in Canada. Canadians were actually ahead of a lot of others in the world. I was in the US and there was nothing happening there. But progress was slow. The provinces, being in charge of both education and health, weren't anxious to jump into nursing education at the quelques années plus tôt, vers 1985, lorsque nos collègues Irene Gataint et Shirley Chance du Red Deer College, en compagnie de la $\mathrm{D}^{\text {re }}$ Janet Ross Kerr de notre université, ont élaboré un modèle de formation en sciences infirmières où un programme de baccalauréat de quatre ans serait exécuté sur le campus du Red Deer College par la faculté des sciences infirmières de la University of Alberta, qui se chargerait de conférer les diplômes universitaires aux étudiantes. C'était le début de la formation collaborative; cependant, le programme n'a vraiment débuté que plus tard. Quand je suis arrivée, en 1987, nous avons dû soumettre une nouvelle proposition pour le mettre en route. Le gouvernement a pris du temps à bouger et à investir; il n'a pas fait avancer le dossier lui-même. Nous avons dû le pousser.

Même auparavant, en 1975, le gouvernement albertain avait formé un groupe de travail sur la formation en sciences infirmières et formulé le premier énoncé sur la nécessité du baccalauréat comme norme pour accéder à la pratique au Canada. Sa position a été approuvée un an plus tard par la College \& Association of Registered Nurses of Alberta; l'idée de soutenir le baccalauréat comme norme pour accéder à la pratique est venue par la suite, en 1995. C'était devenu un mot d'ordre pour toutes les personnes concernées, un objectif à atteindre. Même si le gouvernement a tenté de mettre le plan de côté à la recommandation de son comité, les professionnels et autres parties prenantes du domaine n'ont rien lâché. Par contre, il aura fallu quinze ans pour unir progressivement leurs voix au Canada, alors qu'une association provinciale après l'autre se ralliait au principe d'obligation, pour toutes les nouvelles infirmières, à obtenir un diplôme universitaire de premier cycle. En 1980, le gouvernement a examiné la résolution des qualifications scolaires minimales requises pour la pratique infirmière, et son comité devait étudier la question. Des articles de la revue Infirmière 
university level for nurses. They saw it as a huge unnecessary expense.

However, at the grassroots level, nursing faculty began to look into ways to collaborate among programs as a way of finding resources without getting additional government funding, and that way they could implement new types of programs. One of those early efforts was in BC, where the Vancouver General Hospital School of Nursing undertook a collaborative effort with UBC to offer a baccalaureate degree and give up its own diploma program. Unfortunately, this merger collapsed not too long afterward. In 1995, there was a period of fiscal restraint and the hospital decided to take its money back and left the university to deal with the program by itself. This resulted in a drastic cut to enrolment at UBC because they couldn't afford the program.

Over the rest of Canada at that time, there were some efforts at moving forward on the entryto-practice agenda. For instance, in 1988, the government of PEI announced its decision to faze out the school of nursing education. Around the same time, plans were underway in Newfoundland, Nova Scotia, and New Brunswick to develop collaborative baccalaureate programs. However, nothing was happening in Ontario and Quebec, the two largest provinces with the most registered nurses other than talks between individual universities and colleges. In fact, Ontario jumped on board at the last minute when collaborative programs began to happen across the country. They moved quickly when they did move. Meanwhile, back in Alberta in 1987, we started what would become the collaborative task force for nursing education models. The first meeting was held in Heather Andrews's office at the university hospital. The heads of the five Edmonton nursing programs were present at that meeting. canadienne en abordaient les deux perspectives. Le conseil d'administration de l'Association des infirmières et des infirmiers du Canada (AIIC) a décidé d'appuyer les normes en lien avec le baccalauréat en 1982. À l'époque, cette décision était grandement soutenue au sein de la profession au Canada. En fait, les Canadiens devançaient les populations de bien d'autres pays en cette matière. Quand j'étais aux États-Unis, rien ne bougeait en ce sens. Or, la progression a été lente. Les provinces, responsables de l'éducation et de la santé, n'étaient pas pressées d'adopter la formation universitaire en sciences infirmières. Pour eux, c'était une immense dépense injustifiée.

Sur le terrain, toutefois, le personnel enseignant en sciences infirmières a commencé à chercher des moyens de collaboration, afin que les programmes puissent trouver ensemble des ressources sans un financement supplémentaire du gouvernement; ainsi, elles pourraient instaurer de nouveaux types de programmes. L'un de ces premiers efforts émane de la ColombieBritannique, lorsque la Vancouver General Hospital School of Nursing a décidé, de concert avec la University of British Columbia (UBC), d'abandonner son propre programme menant à un diplôme pour offrir un programme de baccalauréat. Malheureusement, cette association s'est dissoute peu de temps après. L'année 1995 étant marquée par des compressions budgétaires, 1'hôpital a décidé de récupérer ses fonds et laissé l'université s'occuper toute seule du programme. Cette situation a entraîné une baisse dramatique des inscriptions à l'UBC, car l'établissement ne pouvait se payer ce programme.

Dans le reste du Canada à cette époque, quelques efforts tendaient vers l'avancement du dossier concernant l'accès à la pratique. En 1988, par exemple, le gouvernement de l'Îledu-Prince-Édouard a annoncé l'abandon progressif des écoles de sciences infirmières. 
Dr. Nelson: How were the nursing unions on this question? Was there any complication there?

Dr. Wood: No, actually, there were never any complications from the union. The unions were on board because they saw it as beneficial to their members. No, we never had any problem with the unions.

That group in Edmonton, the directors of the hospital schools, the college program, and me were going to become the collaborative task force, but we weren't there yet. There was always an issue on the table between college and university programs and the hospital schools where the hospital schools felt they were the only ones who were teaching clinical practice - the universities and colleges weren't doing that. And the universities and colleges thought that the hospital schools weren't giving any academic background to the students. So there was this issue between the two groups, which was there in every similar situation around the world. For example, I had been in California and it was the same there. We decided that the best thing we could do to solve this issue would be to develop a new program amongst all of us. We could design it as we wished and have it be strong in clinical practice and academics, meeting the needs of the system and we could do anything we wanted. We would then propose to the government that this program be approved and funded. We started that in October of 1987. There were just five of us originally on the task force just from the hospital schools in the Edmonton area and Grant MacEwan College [now MacEwan University]. It was just the one college at that time because we were just looking at Edmonton schools. After this initial meeting, the task force had to grow because we needed more people to do various things. At one point there were 19 members on the main task force.

We were just barely started when Red Deer College decided to join us, although they had
Vers la même période, des plans ébauchés à Terre-Neuve, en Nouvelle-Écosse et au Nouveau-Brunswick prévoyaient la création de programmes collaboratifs de baccalauréat. Rien à signaler du côté de l'Ontario et du Québec, toutefois, nos deux plus grandes provinces, qui comptent la majorité des infirmières autorisées, si ce n'est de pourparlers entre des universités et collèges. En fait, l'Ontario a suivi le mouvement à la dernière minute, lorsque des programmes de collaboration ont commencé à voir le jour un peu partout dans le pays. Dès lors, ils ont agi rapidement. Pendant ce temps, dans l'Alberta de 1987, nous jetions les bases de ce qui allait devenir le groupe de travail collaboratif dédié aux modèles de formation en sciences infirmières. La première rencontre, tenue dans le bureau de Heather Andrews, à l'hôpital universitaire, réunissait les directions des cinq programmes de sciences infirmières d'Edmonton.

Dre Nelson : Quel était 1'avis des syndicats d'infirmières sur la question? Ont-ils engendré des difficultés?

$D^{\text {re }}$ Wood : Non. En fait, les syndicats n'ont jamais entravé notre route. Ils étaient de la partie parce qu'ils comprenaient les bienfaits $\mathrm{du}$ projet pour leurs membres. Non, les syndicats n'ont jamais créé de problèmes.

Ce regroupement d'Edmonton, les directions des écoles en milieu hospitalier, les membres des programmes collégiaux et moi allions former le groupe de travail collaboratif, mais ce n'était pas encore gagné. Un problème persistait entre les programmes collégiaux et universitaires d'une part, et les écoles en milieu hospitalier d'autre part, car ces dernières s'estimaient les seules à enseigner la pratique clinique, ce que n'offraient ni les collèges ni les universités. Ceux-là pensaient pour leur part que les écoles en milieu hospitalier ne donnaient aucune formation théorique aux étudiantes. Il y avait donc cet enjeu entre les deux groupes, qui se reflétait 
their own separate proposal that was developed and ready to be submitted to the government. They decided to join the task force and hold back on implementing their program for a while. They had agreed that the curriculum and the entry-to-practice requirements for them would be the same as the main task force, so they wanted to be part of the discussion. The first students were admitted to that Red Deer College program in the fall of 1990; they were a bit ahead of the larger task force, but not by too much. They chose a model in which first-year students would be admitted through the diploma programs and would transfer to the university at year three of the four-year program. This was what the general structure of the program looked like.

The task force spent two years developing the conceptual basis for the program, and during that time, we handled most of the really contentious issues. By the end of three years, the program proposal had been completed and approved by all the participating institutions. They appointed sub-committees as needed, the major one being the collaborative curriculum coordinating committee which was charged with developing the courses. Dr. Rene Day chaired the group, and they were the most incredibly hard-working group. They got participation from faculty from all the schools in the area, and they all worked as equals. They had meetings, workshops, retreats, educational sessions; they went to visit other programs in Canada and looked at every new and innovative curriculum model. They read everything printed about collaboration and baccalaureate education. In other words, they left no stone unturned.

They came up with a proposal that was not welcomed by the government, whose position on entry-to-practice had not changed. They saw this as a back way of slipping into baccalaureate education without going through the official change. They rejected the proposal, and that resulted in a province-wide dans chaque situation du genre ailleurs dans le monde. Par exemple, j'avais fait le même constat lors d'un voyage en Californie. Nous avons donc convenu que pour régler ce problème, il valait mieux élaborer un programme inédit entre nous tous. Nous pouvions le concevoir à notre gré et faire la part belle à la pratique clinique et à la théorie, pour ainsi combler les exigences du système. Nous pouvions faire tout ce qui nous plaisait. Nous irions ensuite suggérer au gouvernement d'approuver et de financer ce programme. Nous avons démarré le tout en octobre 1987. $\mathrm{Au}$ début, nous n'étions que cinq dans le groupe de travail, issues des écoles en milieu hospitalier de la région d'Edmonton et du Grant MacEwan College (aujourd'hui la MacEwan University). À ce moment, un seul collège participait, car nous ne considérions que les écoles d'Edmonton. Après cette première rencontre, le groupe de travail devait grossir : nous avions besoin de renfort pour accomplir diverses tâches. À un certain moment, le groupe principal comptait dix-neuf membres.

Le projet était à peine entrepris que le Red Deer College décidait de s'y joindre, et ce, même s'il avait sa propre proposition sur les rails, prête à soumettre au gouvernement. Or il a plutôt joint nos rangs et mis son programme sur la glace un moment pour participer à la discussion, convenant que son programme d'études et ses exigences pour accéder à la pratique étaient identiques à ceux du groupe de travail. À l'automne 1990, les premières étudiantes étaient admises au programme offert par le Red Deer College; l'établissement devançait ainsi le groupe de travail, mais de peu. Selon son modèle, les étudiantes de première année étaient admises via les programmes menant à un diplôme, pour ensuite migrer à l'université à la troisième année du programme de quatre ans. C'était l'allure de la structure globale du programme.

Le groupe de travail a pris deux ans pour élaborer le cadre conceptuel du programme, et 
political campaign to get it approved by enlisting the resources of the professional associations for nurses across Alberta. Approval was ultimately procured, and this collaborative program was implemented in 1991. However, because the Alberta government still refused to support the baccalaureate entry-to-practice position, this new program was forced to include a diplomaexit option during the third year of the program at all sites except the university. We did this, and as it turned out, very few students ever selected the diploma-exit option, so it wasn't a big issue.

By 1995, the hospital schools were formally closed by the Alberta government, leaving the collaborative program exclusively in the hands of Red Deer College, Grant MacEwan Community College, and the University of Alberta. Colleges in Grande Prairie and Fort McMurray had already indicated that they wished to be part of the collaborative program. In 1996, students were admitted to the program at those sites as well. Soon, collaborative programs were going on all over Alberta, and all first-year nursing students were entering degree programs for the first time. There was also a conjoint program, started in 1993, between the University of Calgary and the diploma schools at Mount Royal College [now Mount Royal University] and the Foothills Hospital. Then there was a switch of partners, and Mount Royal College became affiliated with Athabasca University. Meanwhile, the collaborative program was initiated between the University of Lethbridge and the colleges in Lethbridge and Medicine Hat. The whole province was now involved.

Although Alberta was at the forefront of the collaboration and was the place where the entry-to-practice movement began, Alberta was one of the last provinces to achieve baccalaureate entry-to-practice. That was because Ralph Klein's premiership was in the 1990s and saw huge cutbacks in funding to nursing education. It created a tremendous durant cette période, il a résolu la plupart des grandes questions litigieuses. Après trois ans, la proposition de programme était achevée et approuvée pour tous les établissements participants. Les sous-comités requis ont été formés, dont le principal, soit le comité de coordination du programme d'études collaboratif, devait concevoir les cours. Le $\mathrm{D}^{\mathrm{r}}$ Rene Day présidait ce comité, un groupe incroyablement assidu. Il a obtenu la participation des enseignantes de toutes les écoles de la région et tous ont travaillé sur un pied d'égalité. Ensemble, ils ont organisé des réunions, des ateliers, des retraites et des séances de formation; ils ont examiné d'autres programmes au Canada et chaque nouveau modèle original de programme d'études. Ils ont parcouru tous les écrits sur la collaboration et l'enseignement au niveau du baccalauréat. Autrement dit, ils n'ont ménagé aucun effort.

Le comité a formulé une proposition, mais le gouvernement l'a rejetée, car il n'avait pas changé d'avis quant à l'accès à la pratique. Il voyait la proposition comme un moyen détourné de passer à l'enseignement du baccalauréat sans passer par le virage officiel. Il a donc refusé, et s'est ensuivi une campagne politique provinciale en faveur de son approbation, avec l'aide des associations professionnelles d'infirmières de partout en Alberta. Le gouvernement a finalement cédé et instauré le programme de collaboration en 1991. Cependant, puisque le gouvernement albertain refusait toujours d'appuyer le baccalauréat comme norme pour accéder à la pratique, ce nouveau programme était obligé d'inclure l'option d'un diplôme de sortie après la troisième année dans tous les établissements, sauf à l'université. Nous avons obtempéré, et en fin de compte, très peu d'étudiantes ont choisi cette option; ce n'était donc pas un problème majeur.

En 1995, le gouvernement avait officiellement fermé les écoles en milieu hospitalier, donnant ainsi l'exclusivité du programme de collaboration au Red Deer College, au Grant 
shortage of nurses by the early 2000s. The government, in order to solve this shortage, opened up additional positions for diploma students through Grant MacEwan College (currently MacEwan University). This was a severe setback to the movement toward baccalaureate entry-to-practice for Alberta. It caused us to be quite late in joining everyone else.

However, the process of collaboration that took place in Alberta and resulted in the collaborative programs, which are still in effect today, was very effective. One was the subject of a qualitative study in the 1990s looking at the interpersonal processes among the collaborators and pointed to the reasons why they were so highly successful in moving toward their goals and in why they had such a good working relationship to carry their project forward beyond implementation. Funding was provided for this study by the Alberta Funding for Nursing Research. This helped us a lot as we were able to identify the key factors as we developed our project. One of the key points was the role of leadership and the manner in which conflict was handled, like the fact that they never used voting to agree on something. They always paused and revisited the issues if there wasn't agreement until consensus could be reached. That was a unique way of proceeding, though it did take a little longer, but it was extremely effective in the long run. Overt conflict was generally avoided, and we used methods such as talking through, compromising, revisiting, and a lot of humour. The ability to deal with conflict directly developed over time as they came to trust each other.

Dr. Paul: Could you talk more about after the hospital schools closed and the $\mathrm{PhD}$ program was brought in. When we had the reunion of the graduates of the $\mathrm{PhD}$ program, you mentioned something I didn't know: some of the money when the hospital schools closed in fact came to the university.
MacEwan Community College et à la University of Alberta. Des collèges de Grande Prairie et de Fort McMurray avaient déjà exprimé le souhait d'intégrer le programme. Dès 1996, des étudiantes s'inscrivaient au programme dans ces établissements. Bientôt, on trouvait des programmes de collaboration partout en Alberta et, pour la première fois, toutes les étudiantes de première année en sciences infirmières suivaient un programme menant à un diplôme. Depuis 1993, la University of Calgary, les écoles conférant des diplômes du Mount Royal College (aujourd'hui la Mount Royal University) et le Foothills Hospital offraient aussi un programme conjoint. Puis, le Mount Royal College a changé de partenaire pour s'associer à l'Athabasca University. Entre-temps, un programme de collaboration était instauré par la University of Lethbridge et les collèges de Lethbridge et de Medicine Hat. Toute la province était au diapason.

Or, si l'Alberta était en première ligne de la collaboration et le berceau du mouvement, c'est l'une des dernières provinces à avoir établi le baccalauréat comme norme pour accéder à la pratique. Cette situation s'explique par le passage de Ralph Klein à la tête du gouvernement dans les années 1990, période marquée par d'énormes coupes dans le financement de la formation en sciences infirmières. Il en a découlé une forte pénurie d'infirmières au début des années 2000. Le gouvernement, afin de résorber cette pénurie, a libéré des places supplémentaires pour les étudiantes en quête d'un diplôme par l'entremise du Grant MacEwan College (la MacEwan University d'aujourd'hui). Il s'agissait d'un grave revers pour le mouvement en appui au baccalauréat comme norme pour accéder à la pratique en Alberta. C'est ainsi que nous avons accusé un retard notable sur le reste du pays.

Par contre, le processus de collaboration qui s'est déroulé en Alberta et d'où découlent les programmes de collaboration encore en 
Dr. Wood: Yes, that's where the money came from for the $\mathrm{PhD}$ program. And we got the approval letter for both programs (collaborative and $\mathrm{PhD}$ program) in the same envelope-I remember very clearly; it was a cold day and my flowers had wilted. The graduate students had given me flowers because we had been successful and gotten these things approved, and it was a very cold day but I had to stop on the way home and it killed them.

While this was all going on to develop a new collaborative program, the faculty was awaiting the $\mathrm{PhD}$ of nursing program, which had been approved in 1986 and hadn't started yet. A task force was initiated to create action on the $\mathrm{PhD}$ program, with a group of 19 graduate students, under the direction of Ginette Lemire Rodger. She had come to Alberta after her position as the executive director of CNA and wanted to get a PhD in nursing in Alberta and not go study in another discipline or outside the province. So the task force, which started with graduate students, was called "Nursing PhD Program: A Reality". They had a very detailed action plan, which included approaching the government at many levels and that each member of the legislative assembly was contacted was contacted between 5 and 200 times, if you can imagine that. They became quite tired of hearing from all of us, and if someone said they were from nursing they would hang up. Nevertheless, it was a successful campaign. All nursing groups in the province were targeted. The campaign was 11 months long, using meetings, phone calls, petitions, publications, visits to the legislature, and it resulted in the mobilization of literally thousands of nurses in support of a doctoral program in Alberta. It was eventually successful, resulting in approval from the province on a freezing cold day in December.

The directors of the hospital schools were most anxious that the money that supported their programs not be lost from nursing. They vigueur de nos jours a été très efficace. L'un d'eux a fait l'objet d'une étude qualitative dans les années 1990, qui traitait des processus interpersonnels parmi les collaborateurs et ciblait les raisons derrière leur grande facilité à atteindre leurs objectifs et les excellentes relations de travail leur permettant de mener leur projet au-delà de sa mise en œuvre. L'étude était financée par le fonds albertain pour la recherche infirmière. Cette aide s'est avérée précieuse, car nous avons pu définir les facteurs essentiels au développement de notre projet. Parmi eux, notons le leadership et la façon de gérer les conflits, les collaborateurs n'ayant jamais eu à voter pour s'entendre sur une question donnée. Ils s'arrêtaient toujours pour revenir sur les questions qui ne trouvaient pas consensus, et ce, jusqu'à ce qu'ils l'atteignent. C'était une manière unique de procéder : un peu lent, mais très efficace à long terme. Le conflit direct était habituellement évité, et les collaborateurs employaient des méthodes comme la discussion, le compromis, la reconsidération, ainsi que beaucoup d'humour. Leur capacité à gérer directement le conflit s'est développée au fil du temps, alors qu'ils établissaient une confiance mutuelle.

$\mathrm{D}^{\text {re }}$ Paul : Parlez-nous davantage de la période suivant la fermeture des écoles en milieu hospitalier et les débuts du programme de doctorat. Lors de la réunion des diplômées de ce programme, vous avez mentionné une chose que j'ignorais: quand les écoles ont fermé, une partie de leur financement a été redirigée vers les universités.

$D^{\text {re }}$ Wood : En effet, c'est de là que venait l'argent du programme de doctorat. Nous avons d'ailleurs reçu les lettres d'approbation des deux programmes (de collaboration et de doctorat) dans la même enveloppe; je m'en souviens très clairement : c'était une journée froide et mes fleurs avaient fané. Elles m'avaient été données par les étudiantes des cycles supérieurs en raison de notre réussite et de l'approbation, mais il faisait très froid ce 
were instrumental in making sure that that money stayed in nursing in Alberta. And that's how we got the money to fund both the collaborative and $\mathrm{PhD}$ programs. It was quite amazing since these people were participating in activities that would lead to the demise of their own programs, but they were mainly for nursing, and they wanted that money for the future of nursing in Alberta. They were quite an amazing bunch of women.

Dr. Paul: Because you brought Ginette to Alberta, and you took the strategy of having the students do some of the work, since the university and the government were not moving on the program I think you were very strategic.

Dr. Wood: Well I tried to be. I always thought, "What would the outcome be if I do this?" And I thought there couldn't be any harm in letting the students mount a campaign of their own. We had very talented students, and they were quite successful at hounding the government and the various other groups who had authority over nursing in the province. Many of those students went on to become the first students in the PhD program.

Dr. Nelson: Did the first cohort of $\mathrm{PhD}$ students go on to be faculty? I suppose they were very conscious that the $\mathrm{PhD}$ program was building capacity in faculty for the baccalaureate program? Were the two programs linked in everyone's mind at the time?

Dr. Paul: When you came, you supported a number of faculty members at the school to go back to study and Dr. MacPhail (the previous Dean) had started that as well. They did PhDs in other fields, but when the $\mathrm{PhD}$ program at the University of Alberta started, those graduates, in great majority, ended up in academic positions.

Dr. Wood: They did, yes.

Dr. Nelson: I'm interested in the connection between the two programs. Both approvals jour-là. J'ai dû m'arrêter sur le chemin du retour et elles n'ont pas survécu.

Pendant l'élaboration d'un nouveau programme de collaboration, les enseignantes attendaient le programme de doctorat en sciences infirmières, approuvé en 1986, mais encore dans les cartons. Nous avons créé un groupe de travail pour œuvrer sur ce programme, composé de dix-neuf étudiantes aux cycles supérieurs, elles-mêmes dirigées par Ginette Lemire Rodger. Après son passage à la direction générale de 1'Association des infirmières et infirmiers du Canada (AIIC), elle venait en Alberta pour y obtenir son doctorat en sciences infirmières, car nulle autre discipline et nulle autre province ne l'intéressaient. Donc, ce groupe de travail, à l'origine formé d'étudiantes, s'appelait «Nursing PhD Program: A Reality » (Le programme de doctorat en sciences infirmières : une réalité). Son plan d'action très détaillé consistait notamment à approcher le gouvernement à divers niveaux et à contacter chaque membre de l'assemblée législative de cinq à deux cents fois, si ça peut vous donner une idée. Ils ont fini par se fatiguer de nous entendre: une mention de notre appartenance aux sciences infirmières, et ils raccrochaient! Quoiqu'il en soit, cette campagne a fonctionné. Elle ciblait tous les groupes de sciences infirmières de la province. Elle a duré onze mois, à force de réunions, d'appels, de pétitions, de publications, de visites à la législature, et elle a entraîné la mobilisation de milliers d'infirmières pour réclamer un programme de doctorat en Alberta. Nous avons finalement obtenu le feu vert de la province par une froide journée de décembre.

Les directions des écoles en milieu hospitalier avaient très peur que les sommes versées à leurs programmes soient détournées des sciences infirmières. Elles ont joué un rôle essentiel en s'assurant de conserver les fonds dans ce domaine et en Alberta. Et c'est comme ça que nous avons pu financer les deux 
came in the same envelope on the same day, and we can see the importance of both of them because you would have needed more PhDprepared faculty members for the profession to move to degree preparation. Was that an argument you made to government? Was that connection being said at the time, that we need a doctoral program to have the degree entryto-practice?

Dr. Wood: The movement toward getting $\mathrm{PhDs}$ for nursing faculty was underway when I arrived in 1987 because Dr. MacPhail had told them all that they must get doctorates or they wouldn't be able to stay in nursing education. During my first few months as the dean, I had one person after another come to see me in my office to check out if this was actually going to be the way it would be, now that I was there. Of course, I was very grateful to Dr. MacPhail for having done this and having everyone on the track of knowing that they needed a doctorate. A lot of people had already made plans and started to take courses. I was happy to support them all to do that. However, they were not able to get their doctorates in nursing unless they left Alberta, which was difficult for people to do midcareer-leave their province, leave their homes and families and go off to school somewhere else. As a result, they were mainly taking their degrees in education, so a $\mathrm{PhD}$ of nursing program was desperately needed in Alberta. We didn't need a situation where all the higher education among faculty was outside the discipline. It was beneficial to all of use to get that program approved so that we could produce our own PhDs in nursing. It would be meeting a lot of needs, for sure. It was fortunate that there was the money from the hospital schools because that's what paid for all of it.

Dr. Paul: That was also because the minister of health at the time, Nancy Betkowski, agreed to this, right? The minister of advanced education didn't want to have anything to do with it, and she told him something to the programmes. C'était plutôt incroyable, car ces personnes s'engageaient dans des activités qui entraîneraient l'arrêt de leurs propres programmes, mais elles agissaient surtout dans l'intérêt des sciences infirmières et voulaient ces fonds pour assurer l'avenir du domaine en Alberta. C'était un groupe de femmes plutôt fantastiques.

D ${ }^{\text {re }}$ Paul : Parce que vous avez attiré Ginette en Alberta et que vous avez décidé de déléguer certaines tâches aux étudiantes, je pense que vous avez été très stratégique, puisque l'université et le gouvernement ne faisaient rien pour le programme.

$D^{\text {re }}$ Wood : Eh bien, j'essayais de l'être. Je me suis toujours dit: «Si je fais telle chose, quel sera le résultat? » Et je pensais qu'il n'y avait aucun mal à laisser les étudiantes organiser leur propre campagne. Nous en avions de très douées, elles talonnaient très bien le gouvernement et les divers autres groupes exerçant un pouvoir sur notre profession dans la province. Bon nombre d'entre elles sont devenues les premières étudiantes du programme de doctorat.

$D^{\text {re }}$ Nelson : La première cohorte de diplômées du programme de doctorat a-t-elle engendré des enseignantes? Je présume qu'il était très clair que le programme créerait un bassin d'enseignantes pour le programme de baccalauréat? A l'époque, les deux programmes étaient-ils liés dans l'esprit de tout le monde?

$D^{\text {re }}$ Paul : Lorsque vous êtes arrivée, vous avez encouragé quelques membres du corps professoral de l'école à retourner aux études, une démarche également entreprise par la $\mathrm{D}^{\text {re }}$ MacPhail (l'ancienne doyenne). Ces professeures étaient déjà diplômées dans d'autres domaines, mais lorsque le programme de doctorat a débuté à la University of Alberta, ces diplômées ont en grande majorité obtenu des postes à l'université.

$D^{\text {re }}$ Wood : En effet. 
effect of that she would cover expenses at the beginning of the program.

Dr. Wood: Yes, she was very supportive of nursing, and she was minister of health during a crucial period. There were others in that position throughout the whole process, but she was a very important minister. She was always receptive to any of us who came to see her about an issue like this. She was easy to talk to.

Dr. Nelson: We would like to hear your thoughts on what you think was the most interesting development in nursing education during your career.

Dr. Wood: The development of the independence of the schools of nursing was probably the one that created the biggest change that I saw. Schools were very dependent on hospitals at the very beginning, and that became less and less, and schools became quite independent. That really made a difference in what schools of nursing were able to accomplish and the directions they were able to take.

Dr. Nelson: When did that happen?

Dr. Wood: That would have been during the nineties.

Dr. Paul: Our last question is related to staff mixing in the hospitals. In Alberta, in the last five years, there has been an increasing reliance on practical nurses (PNs), and undergraduate students are having a harder time finding positions.

Dr. Wood: This has happened before. It's always a mistake.

Dr. Paul: Absolutely. In some ways, the government has always been opposed to entryto-practice, and PNs now have the equivalent of what used to be the diploma. Their programs are quite similar to the old $\mathrm{RN}$ diploma programs. So this raises the question of what will come in the future? How many renditions will we have?
$D^{\text {re }}$ Nelson : Je m'intéresse au lien entre les deux programmes. Les deux approbations sont arrivées dans la même enveloppe, le même jour, et on peut voir l'importance des deux, car vous auriez besoin d'enseignantes mieux préparées au doctorat, alors que toute la profession se dirigeait vers le baccalauréat comme norme pour accéder à la pratique. Avez-vous servi cet argument au gouvernement? Ce lien était-il énoncé à l'époque, soit la nécessité d'avoir un programme de doctorat pour faire du baccalauréat une norme pour accéder à la pratique?

$D^{\text {re }}$ Wood : Le mouvement vers l'obtention de doctorats par les membres du corps professoral était déjà enclenché quand je suis arrivée en 1987, car $\mathrm{D}^{\text {re }}$ MacPhail leur disait que sans doctorat, elles ne pourraient plus enseigner les sciences infirmières. Pendant mes premiers mois à titre de doyenne, les gens se succédaient à mon bureau pour vérifier si ce serait vraiment le cas, maintenant que j'occupais cette fonction. Bien sûr, j'étais très reconnaissante pour les actes de $\mathrm{D}^{\text {re }}$ MacPhail, soit d'informer tout le monde de la nécessité d'un doctorat. Elles étaient déjà nombreuses à s'organiser et à suivre des cours en conséquence. J'étais heureuse de les soutenir toutes en ce sens. Cependant, elles ne pouvaient obtenir de doctorat en sciences infirmières qu'en quittant l'Alberta, ce qui était difficile à faire en milieu de carrière : quitter sa province, son domicile et sa famille pour aller étudier ailleurs. De fait, elles s'orientaient principalement vers le diplôme en enseignement. L'Alberta avait désespérément besoin d'un programme de doctorat en sciences infirmières. Nous ne voulions pas que toute la formation supérieure de nos enseignantes émane d'une autre discipline. L'approbation de ce programme profitait à toutes, puisque nous pourrions produire nos propres diplômées du programme de doctorat en sciences infirmières. De toute évidence, cela allait combler beaucoup de 
Dr. Wood: It takes a while for the effects of these things to become apparent to everybody. Things will seem to be doing alright for a while, and then situations start to collapse as they don't have registered nurses in key positions. Then they have to rush to fix that. We've seen that happen in the US, too. When I was in California, they started replacing RNs with practical nurses, called LVNs there, and it was a mistake there and it's a mistake here. It's hard to get people to see that in advance. I'm sorry to hear that it is currently happening again.

Dr. Paul: It is happening again, but eventually the wheel will turn in the right direction once more.

Dr. Wood: It was really terrible in the 1990 s when the graduates from our programs couldn't get jobs, and they left the province as a result. An awful lot of nurses had to leave Alberta in order to find work - many went to the US or other provinces. It was assumed when we needed them they would rush back, but when we needed them, they didn't come. Then there was a terrific shortage of nurses. This didn't work in our favour, however, because the easiest way for the government to deal with the shortage was to put more diploma nurses in, which is what they did.

Dr. Nelson: The problem with it, too, is that, at least in Ontario, the scope of practice for a registered nurse and a practical nurse is now the same, as the CNO have changed things over the past few years. There's nothing an RN can legally do that a PN can't; it's all down to the assessment of the patient and whether the nurse has the competence and knowledge. But many would argue that this blurring of scope of practice between the two levels of nurse has meant that we've brought back in, under another name, a diploma-type of registered nurse and a degree-type of registered nurse, at least functionally. From an employer's point of view, you've got a cheaper to prepare and cheaper to pay less educated nurse, who is now besoins. Et heureusement que nous avions les fonds des écoles en milieu hospitalier, car ils ont permis d'éponger la facture.

$D^{\text {re }}$ Paul : C'est aussi parce que la ministre de la Santé de cette époque, Nancy Betkowski, a donné son aval au projet, n'est-ce pas? Le ministre de l'Enseignement supérieur ne voulait pas s'impliquer, et elle lui a dit quelque chose du genre qu'elle couvrirait les dépenses à l'instauration du programme.

$D^{\text {re }}$ Wood : Oui, elle soutenait beaucoup les sciences infirmières et dirigeait la Santé pendant une période cruciale. D'autres ont occupé ce poste tout au long du processus, mais elle a été une ministre très importante. Elle se montrait toujours réceptive lorsque l'une de nous l'approchait pour discuter de la question. Elle était facile d'approche.

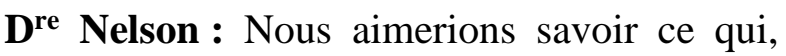
selon vous, constitue la plus intéressante avancée en matière de formation en sciences infirmières durant votre carrière.

$D^{\text {re }}$ Wood : À ma connaissance, le processus d'autonomisation des écoles de sciences infirmières est probablement ce qui a créé le plus grand changement. Les écoles dépendaient beaucoup des hôpitaux au tout début, puis cette dépendance s'est progressivement estompée jusqu'à ce que les écoles acquièrent une bonne autonomie. $\mathrm{Ce}$ phénomène a vraiment contribué à leur capacité d'accomplissement et d'exploration de différentes orientations.

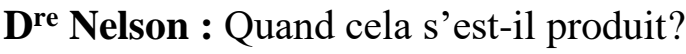

D $^{\text {re }}$ Wood : Je dirais, pendant les années 1990.

$D^{\text {re }}$ Paul : Notre dernière question se rapporte à la composition du personnel dans les hôpitaux. En Alberta, au cours des cinq dernières années, les établissements recouraient de plus en plus aux infirmières praticiennes (IP), et les étudiantes de premier cycle ont beaucoup de difficulté à se faire embaucher. 
a major part of the workforce. It's one step forward, two steps back.

Dr. Paul: That must be incredibly frustrating for you and your faculty to no end.

Dr. Nelson: It comes back to your earlier point, that the impact of these things can be hidden for some time.

Dr. Wood: Yes, people think that their solution to the problem has been successful, until they begin to see the impact of not having a sufficient number of registered nurses in the system.

Dr. Nelson: We see that now in the long-term care homes and the death rate with Covid-19. Canada is one of the worst in the world in terms of the vulnerability of people in longterm care. Many of the registered nurses have been removed from that sector. We have a very small number of RNs and PNs, and the care providers are minimally educated. And poor accreditation. It's nothing that people haven't been warning about for 10 or 15 years. The problem is now undeniable.

Dr. Wood: It takes quite a while to resolve that problem even once they identify it. It will go on for some time, and it's a cumulative effect. Then it's hard to set it right.

Dr. Paul: To have to reorganize things that have basically been demolished.

Dr. Nelson: The other point of yours that I take from this is that you have to get everyone in the same place. You have to get the employers, the directors of nursing, the community colleges, the universities, the government, and the unions all in the same place, and that takes time and a lot of work.

Dr. Wood: That's the most work of all. But nothing will change unless that work does happen. You have your work cut out for you!

Dr. Paul: Thank you so much for answering our questions.
D ${ }^{\text {re }}$ Wood : C'est arrivé par le passé, et c'est toujours une erreur.

$D^{\text {re }}$ Paul : Tout à fait. D'une certaine manière, le gouvernement s'est toujours opposé aux mesures d'accès à la pratique au niveau débutant, et les IP ont maintenant l'équivalent de ce qui était autrefois le diplôme. Leurs programmes ressemblent pas mal aux vieux programmes menant à un diplôme des infirmières autorisées. Alors la question, c'est : que nous réserve l'avenir? Combien y aura-t-il d'interprétations de l'accès à la pratique?

$D^{\text {re }}$ Wood : Il faut du temps pour que les effets de ces décisions soient connus de tous. Les choses vont sembler bien aller pendant un certain temps, puis les situations se détérioreront parce qu'aucune infirmière autorisée n’occupe de poste clé. Il faudra donc se dépêcher à rectifier le tir. La même chose s'est produite aux États-Unis. Quand j'étais en Californie, ils ont commencé à remplacer les infirmières autorisées par des praticiennes, appelées «Licensed Vocational Nurses» (infirmières professionnelles certifiées); c'était une erreur là-bas et c'en est une ici. Il est difficile pour les gens de le prévoir. Je suis désolée d'apprendre que la situation se répète actuellement.

$\mathbf{D}^{\text {re }}$ Paul : Elle se répète, oui, mais un jour, la roue tournera de nouveau dans la bonne direction.

$D^{\text {re }}$ Wood : C'était vraiment terrible dans les années 1990, quand les diplômées de nos programmes ne trouvaient pas d'emplois, ce qui les a forcées à quitter la province. Un très grand nombre d'infirmières ont dû s'exiler pour travailler, soit aux États-Unis, soit dans une autre province. Nous supposions qu'elles reviendraient à la course quand le besoin se ferait sentir, mais en vain. Une énorme pénurie s'est ensuivie, ce qui n'a même pas joué en notre faveur, puisque pour le gouvernement, la solution la plus simple consistait à embaucher 
encore plus d'infirmières de formation professionnelle.

$D^{\text {re }}$ Nelson : L'autre problème, du moins en Ontario, c'est que le champ de pratique des infirmières autorisées et praticiennes est désormais identique, car l'Ordre des infirmières et infirmiers de l'Ontario a modifié des éléments au cours des dernières années. D'un point de vue légal, ce qu'une IA fait, une IP peut aussi le faire; tout dépend de l'évaluation du patient, puis des compétences et des connaissances de l'infirmière. On pourrait avancer que d'une perspective fonctionnelle, cette confusion des champs de pratique entre ces deux types d'infirmières signifie que nous avons de nouveau, sous une autre appellation, des infirmières autorisées détentrices d'un diplôme et des infirmières autorisées détentrices d'un baccalauréat. Dans l'œil des employeurs, vous avez des infirmières plus abordables en matière de formation et de rémunération, mais avec une formation moindre, qui constituent la majeure partie des effectifs. Un pas en avant, deux pas en arrière.

$D^{\text {re }}$ Paul : Un phénomène qui doit vous frustrer au plus haut point, votre corps professoral et vous.

$D^{\text {re }}$ Nelson : Cela reflète ce que vous disiez plus tôt: les effets de ces décisions peuvent rester longtemps dans l'ombre.

$D^{\text {re }}$ Wood : Oui, les gens pensent que leur solution a été efficace, jusqu'à ce qu'ils voient l'incidence d'un manque d'infirmières autorisées dans le système.

$D^{\text {re }}$ Nelson : Nous le constatons actuellement dans les établissements de soins de longue durée et lorsque nous considérons le taux de mortalité liée à la COVID-19. Le Canada est l'un des pires pays en ce qui a trait à la vulnérabilité des personnes vivant dans ces établissements. De nombreuses infirmières autorisées ont été retirées de ce secteur. Il y a très peu d'IA et d'IP, et les fournisseurs de 
soins n'ont qu'une formation de base. L'agrément se fait rare. Ce n'est pas comme si les gens n'étaient pas avertis depuis dix ou quinze ans. Le problème est indéniable.

$D^{\text {re }}$ Wood : Il faut un certain temps pour régler ce problème, même une fois ciblé. La situation va perdurer pendant un moment, car elle a des effets cumulatifs. Il est par ailleurs difficile de la rétablir.

$D^{\text {re }}$ Paul : De réorganiser les choses qui ont essentiellement été démolies.

$D^{\text {re }}$ Nelson : Ce que je retiens également de votre discours, c'est que tout le monde doit pagayer dans le même sens. Il faut que les employeurs, les directions des sciences infirmières, les collèges communautaires, les universités, le gouvernement et les syndicats se mettent au diapason, ce qui prend du temps et beaucoup de travail.

$D^{\text {re }}$ Wood : C'est la tâche la plus imposante. Mais rien ne changera tant que ces efforts ne seront pas déployés. Vous avez du pain sur la planche!

$D^{\text {re }}$ Paul : Nous vous remercions infiniment d'avoir répondu à nos questions. 